\title{
Political and Social Struggle of Ghazi-e-Millat Sardar Muhammad Ibrahim Khan: Freedom of Kashmir
}

\author{
Amar Jahangir ${ }^{*}$ \\ Anbrin Khawaja** \\ Unsa Jamshad $^{* * *}$
}

\begin{abstract}
Although a few research studies are available on the Kashmir, Sardar Muhammad Ibrahim Khan, Freedom Movement of Kashmir and the establishment of Azad Kashmir Government. In this paper, an attempt has made to study and analyze the role of Sardar Muhammad Ibrahim Khan in the Freedom Movement of Kashmir, especially in the Establishment of Azad Kashmir Government. Sardar Muhammad Ibrahim Khan led the country during an era when the entire subcontinent was enslave by the British Empire. He has emerged as a national leader who has brought the nation together. On 19 July 1947, he passed a resolution of Accession with Pakistan. Because of his political and social struggle on 24 October 1947 a massive area became independent and announce the revolutionary government of Azad Kashmir.
\end{abstract}

Keywords: Sardar Muhammad Ibrahim Khan, Political and Social Struggle, Freedom Movement and Azad Kashmir

* PhD Scholar, Department of History and Pakistan Studies, IIUI, Islamabad. email: amirjahangir82@ gmail.com

** Assistant Professor, Institute of Kashmir Studies, UAJK, Muzaffarabad.

${ }^{* * * *}$ Assistant Professor, Department of History and Pakistan Studies, WUAJK, Bagh 


\section{INTRODUCTION}

Allah the Magnificent has blessed many people with many marvelous qualities. Few are blessed with wealth, honor and prosperity, and they become the leader of their nation. Sardar Muhammad Ibrahim Khan is one who belongs to these few people. Sardar Muhammad Ibrahim Khan has led the nation at the time when the whole subcontinent was stuck under the slavery of British Empire. Sardar Muhammad Ibrahim Khan has emerged as a leader of the nation who united them.

\section{Family Background}

Poonch was one of the important tenements of the state of Jammu and Kashmir, which was inhabited by many independent tribes. These tribes have raised their voices to get freedom at various ages. ${ }^{1}$ Sardar Shams Khan, Sardar Milli Khan, Sardar Sabiz Ali Khan, Sardar Bahadur Ali Khan, Colonel Khan Muhammad Khan, Captain Hussain Khan, Captain Bostan Khan, and many renowned heroes were born in the land of Poonch. These heroes have their place in the hearts of the people due to their great sacrifices and the achievements they have made during struggle for the freedom.

\section{SARDAR MUHAMMAD IBRAHIM KHAN'S EARLY YEARS}

Ghazi-e-Millat Sardar Muhammad Ibrahim Khan was born on April 22, 1915 at a village Hurna Mera district Rawalakot (Poonch). At that time, the Poonch Tenement was ruled by Raja Baldev Singh the son of Raja Moti Singh. In this regard Sardar Rasheed Hussain Bloch has written as; Sardar Muhammad Ibrahim was born at the home of Sardar Muhammad Alam Khan in 1915 at village Kot Matty Khan 15 km from Rawalakot." 2

\section{Primary Education}

Gazi-e-Millat Sardar Muhammad Ibrahim Khan has receive his elementary education from his native village. He has learned Quran from his elder brother Sardar Mir Alam Khan, and then got admission in the primary school. He completed the primary education within three years with first position in the center of all the 20 primary schools of the Sodhnoti. He has written about his elementary education in his book as; "I use to do the household work from the very young age. Nobody at my home was interested to send me at school and neither, I am valued at home. While all the children of the village were going to school, and nobody has made his mind to send me to the school. Therefore, my elder brother's son was getting ready for the school. My father was mostly out of home for work, while we all learn Quran from our elder brother. But I didn't get much success in that education and neither, we get involved."3

About his elementary education in an interview to Asian Weekly News he said; "I was around the age of ten to twelve years when got admitted to primary school. Already much of the time

\footnotetext{
${ }^{1}$ Sardar Muhammad Ibrahim Khan, "Matha-e-Zindagi” Dherti Publisher Rawalakot p. 14

${ }^{2}$ Rashid Hasrat, “Gazni say Kashmir Tak Dastan Mardan Hurr 'Sudhan' Dairatul Muarif” Waqas Innayat Publishers Foundation Rawalpindi. p.301

${ }^{3}$ Op.Cit., Sardar Muhammad Ibrahim Khan, "Matha-e-Zindagi”,p. 14
} 
was lost that is why I have given exam of the two classes together. After that I have given collective exam of primary in Bahrri the village of Pachiot. Headmaster Fateh Muhammad took our exam. Approximately one fifty students from all the schools were appeared in that exam. I used to attempt and solve the exam paper first of the all. The Headmaster was of the doubt that this boy has done cheating/ used unfair means. The same he expressed to my brother, who replied to check his answer. When I got up after attempting the fifth questions, the Headmaster said to my brother that he is really intelligent. He further asked where he lives does. On this, my brother revealed that this is my younger brother, and he has got first position in these twenty five schools."

Sardar Muhammad Ibrahim Khan after completion of the primary education had taken admission in High School Poonch as a boarder. Where he met Sardar Habib Khan, for which he expressed to Weekly Asian News in an interview as" "Where I got the company of Sardar Habib Khan, who despite all the difficulties continued his education. His strict nature motivated to join the army but due to the grievances of his father, he continued the education, and in matriculation, he had missed the first division with just ten marks." 5 Sardar Rasheed Hussain Bloch has written about the Sardar Ibrahim Khan and Sardar Habib's educational scholarship as; "Sardar Habib told that we both (Sardar Ibrahim Khan and Sardar Habib) were getting ten rupees scholarship from the Sudhan Educational Conference". 6

\section{Higher Education}

In 1933 after passing the matriculation exam Sardar Ibrahim Khan decided to continue his education as wished by his father. For this purpose, he had to decide to go to Lahore or Srinagar for higher education. Srinagar can be a better choice in terms of expenses and distance, but Sardar Ibrahim Khan decided to take admission in Islamia College Lahore. He has described about his education in Lahore in his book as; in matriculation, Habib scored more marks than I did, and he was getting 3/4 scholarships. My obtained marks were not so good, because I was not a bookworm. I used to participate in games along with the study. Habib was more intelligent and hardworking then me. However, admission was not difficult because our teacher Mr. Molvi Nazir Ahmed was also present in Lahore. ${ }^{7}$

Sardar Muhammad Ibrahim Khan remained in Lahore for four years (1933-1937) for education. During that time, he worked hard and got success. In this regard Syed Mahmood Khan said in his book as; "After matriculation from Poonch, he went to Islamia College Lahore for FA in 1933. After completing FA, he got admission in BA in Punjab University and return to home after completing BA in 1938. During that time, his father and brother decided for sending him abroad for higher education. For that purpose, he already collected necessary information and guidance for higher education in London during his stay at Lahore for education. His brother Sardar Ismail Khan on his visit to Lahore to meet him asked about his plan after completing BA. He expressed

\footnotetext{
${ }^{4}$ Asian Weekly News, Editor Zahid Qurashi p.20.

${ }^{5}$ Ibid

${ }^{6}$ Op.Cit. Rashid Hasrat, “Gazni say Kashmir Tak Dastan Mardan Hurr 'Sudhan' Dairatul Muarif”, p.301

${ }^{7}$ Op.Cit. Sardar Muhammad Ibrahim Khan, "Matha-e-Zindagi”, p. 33
} 


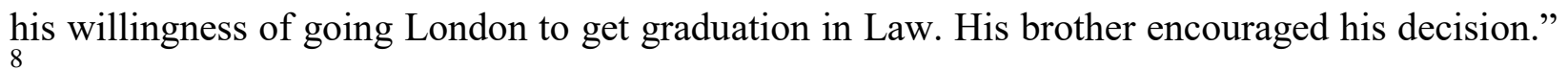

When the people of Sardar Muhammad Ibrahim Khan's native village came to know about his wish, they became happy and surprised at the same time. Because at that time it was very difficult to get education even up to matriculation and Sardar Muhammad Ibrahim Khan, was ready to get education from Britain. In order to fulfil his wish his brothers made necessary arrangements by contacting different people to meet his financial expenditures.

\section{Journey to Britain}

After the necessary financial arrangements' Sardar Muhammad Ibrahim Khan along with his brother Sardar Muhammad Ismail Khan traveled to Lahore. Where through bank, the amount was transferred to Britain, and they left for Mumbai (Bombay). In this reference, Masood Khan has written about Sardar Muhammad Ibrahim Khan "Gazi-e-Millat" as; On submission of the amount, Mr. Sardar left for Mumbai (Bombay) accompanied by his brother. Those times there was no air travel, and it was made through the ship which was difficult and quite long. After reaching Mumbai (Bombay) Ismail Khan has dropped his brother on the Ship and the name of that ship was SS Conti Rasu. ${ }^{9}$

After fifteen day's journey, the ship reached at the Venice the port of Italy. Where the passengers landed from the ship and those heading to Britain continued their journey through train via Paris reached their destination. After reaching Britain the biggest issue for Sardar Ibrahim was the arrangements for his accommodation. After a little struggle, it was also resolved. Sardar Ibrahim has discussed this in his book as; "First I have taken admission in Linkins then went to India House to give application for accommodation. One big mistake done by me was that I went there at the odd time for admission in the University. As University was close because of vacations in the July, and the classes ought to be start by September, and I was there by March. Its round about three months where I was wondering, which can be dangerous for a young person. After due deliberations, I have purchased my books of law and stared studying them. During that time, my host served me in such a way that my mother might not do. She (host) knew that excellent way of serving that can be achieved after the training of years for our people." 10

During Second World War Sardar Muhammad Ibrahim Khan was in Britain. Whole of the world was affected by it. Syed Mahmood Khan Said in his book as; he left for England in 1940 for graduation in law took admission in London University. He was hardworking and devoted to studies. It was the time of Second World War. Whole of the Europe was under the dangerous war threat. However, Sardar Muhammad Ibrahim Khan was completely focused to his activities of his study." 11

8 Syed Mehmood Azad, "Sardar Muhammad Ibrahim Khan ki Sayasi Sawan-e-hayat". Sadat publisher Mzaffarabad, p.2

${ }^{9}$ Masood Khan, "Sardar Muhammad Ibrahim Khan ki Sayasi Sawan-e-Umri» Lahore: Maqbool Academy, p.34

${ }^{10}$ Op.Cit. Sardar Muhammad Ibrahim Khan, "Matha-e-Zindagi”, p. 35

${ }^{11}$ Op.Cit. Syed Mehmood Azad, "Sardar Muhammad Ibrahim Khan ki Sayasi Sawan-e-hayat", p.2 


\section{Returning From Britain}

After successful completion of LLB and Barrister, he return from Britain in 1941. After threemonth long journey in January 1942 he landed at the Kolkata Port. He had no communication with home due to war. That is why he was much worried about his mother, either she was alive or not. By chance, he met with one of his relatives there and became happy to know that his mother is alive. At the same time, he was shocked to hear about the death of his father who had sent him abroad for higher education. Sardar Ibrahim when returned to home that day was a historical day for the whole area. He was the first barrister of the whole state of Azad Jammu and Kashmir. Sardar Ibrahim has discussed about his Journey back to the subcontinent in his book as "I spent 10 rupees in whole four-year tenure at abroad where I got LLB and Bar at Law degrees from London.", 12

\section{Government Employment}

After returning home, he visited Poonch and later Jammu for Government Employment. However, was not successful though he was the first barrister of the state of Azad Jammu and Kashmir. After that, he went to Srinagar. About this he have discussed in as; "The struggle for Job in Srinagar was continued when the chief minister of the Maraja Harri Singh resigned from his position. While I decided to start practicing in Srinagar Court. I acquired the license and started practice when the Kalash Zain started as a Temporary chief Minister. He himself called upon me and asked for my joining at a vacant position of the government lawyer. I agreed for that job after consulting my friends, and I was deputed to Mirpur." 13

In Mirpur, Most of the officers and lawyers were Hindus. Whom had the biased attitude towards Sardar Ibrahim. In this reference Masood Khan written as; "Among them the session Judge was Hindu and most of the lawyers. All of them kept biased attitude with Sardar Ibrahim."14 In those circumstances, it was difficult for Sardar Ibrahim to continue job with Hindus. However, he remained attached with his utmost skills and got success, and made many people his accordant.

\section{Marriage and Marital Life}

In 1943 after getting the government job he agreed for marriage because of his mother insisted. He wrote about his marriage as per my mother's insistence, I got agreed for marriage. And also I have given the mandatory condition of two weeks for the entire process of marriage because I don't like the hanging decisions. The daughter of the most honorable decent personality of the area (Haji Qasim Khans) got agreed to marry me. The marriage was done within 15 days. ${ }^{15}$

After Marriage Sardar Ibrahim has taken his family with him. First, he lived in Mirpur and later in Jammu. His first son Javed Ibrahim was born at Mirpur. Sardar Ibrahim was much caring for his people that once in an interview to Asian News, he said; "If we the young men of the

\footnotetext{
${ }^{12}$ Op.Cit. Sardar Muhammad Ibrahim Khan, “Matha-e-Zindagi”, , p. 55

${ }^{13}$ Ibid, p. 101

${ }^{14}$ Op.Cit. Masood Khan, "Sardar Muhammad Ibrahim Khan ki Sayasi Sawan-e-Umri", p. 41

${ }^{15}$ Op.Cit. Sardar Muhammad Ibrahim Khan, "Matha-e-Zindagi”, p. 119
} 
mountains after getting higher education and higher position get married to the women outside, then what will become of the loyal and simple girls of our country.",16

\section{Resigned from Government Job}

In those days, Jammu and Kashmir were under state terrorism by Dogra Government, and Pakistan's movement was on its peak, in which Kashmiri Muslims fully participated. People of the Poonch were playing a leading role in the Pakistan movement and freedom struggle against Maraja Hari Singh. In view of the situation and its long-term consequences, Sardar Ibrahim resigned from the government job and decided to play a leading role for his people. People were also not happy by his government job, and neither he was satisfied. In this regard he has mentioned in his book as; "When I resigned a Hindu chief Minister was hesitating to approve it. He was not believing that a Muslim assistant advocate general can resign from his designation. It was the time when only few Muslim clerks were seen in the offices and possibility for Muslim officers was beyond imaginations.",17

In spite of Sardar Ibrahim's promotion to assistant advocate general and his further promotion into advocate general was quite evident. He resigned due to bias attitude of Hindu officers as well as his motivation towards welfare and serving the people. He said, "When I resigned the people call it a madness. When you want to get something without any greed then many other ways naturally get open for you. In those days when I resigned, all the leaders of the Muslim Conference were arrested unnecessary due to movement. I have started politics with passion and courage. I accepted every danger as ambition of my life. ${ }^{18}$

\section{Entry in the Politics}

When Sardar Ibrahim resigned from the government job and entered into the politics, the All Jammu and Kashmir Muslim Conference was in crises due to the conflict between its important leaders such as Choudhry Hammed Ullah and Mir Waiz Usaf Shah. The National Conference was the famous political party of the valley. In this reference Sardar Ibrahim has written in his book as; "In the history of Jammu and Kashmir it was the most critical situation. In India, the circumstances are changing very quickly. The division of India was quite evident. The position of Sheikh Abdullah's Kashmir valley was much strong." 19

After the formation of National Congress, the people of the State of Jammu and Kashmir was divided into two parts. Sardar Ibrahim wrote in his book as; "The All Jammu and Kashmir Muslim Conference remained in existence till June 1938. It held six annual sessions in all. In 1938 Sheikh Muhammad Abdullah and Ch. Ghulam Abbas agreed to alter the political structure of the All Jammu and Muslim Conference by calling it a National Conference" ${ }^{20}$

\footnotetext{
${ }^{16}$ Op.Cit. Asian Weekly News, p.201

${ }^{17}$ Op.Cit. Sardar Muhammad Ibrahim Khan, "Matha-e-Zindagi”, p. 101

${ }^{18}$ Ibid p. 106

${ }^{19}$ Ibid p. 2011

${ }^{20}$ Sardar Muhammad Ibrahim Khan, “Kashmir Saga” Dherti Publisher Rawalakot p. 32
} 


\section{Joining of All Jammu and Kashmir Muslim Conference}

Sardar Muhammad Ibrahim Khan after resigning from the government job in 1946 joined All Jammu and Kashmir Muslim Conference and later became its chief organizer. In this regard, Professor Dr. Muhammad Sarwar Abbasi written in his book as, "Muslim Conference Party was constituted on March 26, 1947. Party has elected Choudhury Hameed Ullah as President, Khawaja Ghulam as Vice president, Sardar Yar Muhammad Khan as Secretary and Sardar Ibrahim as Chief Organizer. Party has taken oath that it will strive within and outside of the Assembly for Azad Kashmir." 21

Sardar Ibrahim expressed his views about the conflict in Muslim Conference leadership in an interview in these words "On the question of group leadership of Muslim Conference in the Assembly; many of the Muslim Conference members did not agreed on the name of Choudhury Hameed Ullah. However, they agreed for me, but I refused. It was not because I didn't have concern, but because I was inexperienced." ${ }^{, 2}$

\section{Participation in the Assembly Elections and Success}

The Dogra government and State of Jammu and Kashmir decided to conduct general election on Jan 4, 1946 keeping in view of the fact that due to winter election, polling will have minimum participation. Whereas, the Sardar Ibrahim had already joined Muslim Conference so in the constituency of the Sudhanoti the elected member Colonel Khan, Muhammad Khan of the same party has given their place to Sardar Ibrahim. In this reference, written in his book as; "First state elections conducted in 1935, where in Poonch Constituencies, Manddar and Hawali Fateh Muhammad Kralvi, and Bagh and Sudhanoti Colonel Khan Muhammad Khan was successful. Both leaders in the assembly struggled for the approval of their demands, but from 1935-1946, they were unable to get approval of their demands despite their hard struggle. Hence in the general elections of 1946, both decided to leave their respective seats." 23

When Sardar Ibrahim was nominated for Bagh and Sudhanoti, this constituency included the areas of present day Kohala, to Sensa and ended at Ser Sawa, Kotli. In this constituency, the unavailability of the transportation led Sardar Ibrahim traveled in the entire area by foot and demanded people for the vote. In this regard, Masood Khan has written in his book as; "In this whole constituency, the campaign was on foot, which was quite difficult. On the other hand, he did not have enough financial resources to contest the elections. Luckily, first of all, from Dirkot where the Khan Muhammad Khan was quite famous campaigned along with Sardar Ibrahim. Where he told the people that from now onwards Sardar, Ibrahim will represent them in the assembly. That's why people of this area accepted Sardar Ibrahim as their leader." 24

After the nomination of Sardar Ibrahim by Muslim Conference, the people of the Poonch fully supported him during his campaign. Syed Mahmood Azad in his book writes, "When Sardar

\footnotetext{
${ }^{21}$ Dr. Muhammad Sarwer Abbasi, Kashmiri Musalmau ki Jehdojehd-e-Azadi, Muzaffarbad: Publisher IKS AJKU ,p.24

${ }^{22}$ Op.Cit. Asian Weekly News, p.201

${ }^{23}$ Syed Mehmood Azad, "Sardar Muhammad Ibrahim Khan ki Sayasi Sawan-e-hayat". Mzaffarabad: Sadat Publisher, p. 06

${ }^{24}$ Op.Cit. Masood Khan, "Sardar Muhammad Ibrahim Khan ki Sayasi Sawan-e-Umri", p.47
} 
Ibrahim first time visited Bagh the people deliriously moved to the gathering place to see him, and Sardar Ibrahim became the common subject of discussions at home. Sardar Ibrahim has got such a popularity in those days in his constituency which; any other leader cannot imagine for years. Within few days, he achieved a place in the hearts and minds of the people. ${ }^{25}$

\section{Representation in the Assembly Session}

After the success in the general elections' Sardar Ibrahim first time participated in the budget session of the Assembly. He has opposed the Dogra government policies in a confident and responsible manner. There were fewer numbers of elected as compared to the nominated members in the Assembly of the State of Jammu and Kashmir. That is why the legislation, here was quite difficult because the Assembly kept in mind the interests of Mahraja. A different and educated legislator could not be bound to express his liberal approach. Sardar Muhammad Gulfaraz in his book has written as; Sardar Ibrahim started the post- mortem of the Assembly's idea, script and its legal standing. He never left any chance for analysis, discussion and criticism. Hence, first time the Assembly was criticize.

The demand for more elected members of the Assembly by Sardar Ibrahim was gaining popularity day by day. This popular demand became the reason for the issues for Mahraja. On the other hand, due to the imprisoning of the leadership of Muslim Conference, there was very strong disagreement in the election of the leadership. This can be narrate from Syed Mahmmod Azad's book, "At that time, there was difficulty of Muslim Conference leadership within the Assembly party. Many members of the Muslim Conference did not agree on the name of Choudhury Hameed Ullah as a party leader. However, they were agreed for Sardar Ibrahim, who refused." 26

\section{Resolution of accession with Pakistan}

In the meanwhile based on Two Nation Theory; on the demand of the people of the subcontinent, on June 3, 1947, the formula for division of India was presented. Sardar Ibrahim in accordance with the situation to apprised the people of state of Jammu and Kashmir he visited especially his own constituency.

Because of his convincing to the people of Jammu and Kashmir to opt for Pakistan, Sardar Muhammad Ibrahim Khan was confine at Srinagar and restricted to enter in the State of Poonch by Dogra Administration. At that time, Sardar Muhammad Ibrahim Khan met with leaders of Valley and Jammu of Muslim Conference and started discussion about accession with Pakistan. After long discussion, he was able to convince the leaders to approve the resolution of accession with Pakistan. It was great achievement of Sardar Muhammad Ibrahim Khan and challenge for Dogra Raj. ${ }^{27}$

\footnotetext{
${ }^{25}$ Op.Cit. Syed Mehmood Azad, "Sardar Muhammad Ibrahim Khan ki Sayasi Sawan-e-hayat", p. 08

${ }^{26}$ Sardar Muhammad Gulfiraz Hijazi, "Tarikh Tehrik-e-Kashmir Inqlab Poonch 1947”, Mirpur: Verinag publisher, p. 76

${ }^{27}$ S.H.S Gardazi, “Tareekh-a-Aazadi-e-Kashmir ka Paasa Manzar”. Vari Nag Publisher Mirpur p. 108
} 
After this historical resolution of accession to Pakistan, Sardar Muhammad Ibrahim Khan wrote an oath paper on which member of meeting signed. Following were the clauses of this oath paper.

"We are taking sword by name of Allah and Muhammed (S.A.W.W) that we will start retardation against Marajah Hari Singh if he did not accept the accession of Kashmir with Pakistan and before 15 August if any clash started in Bagh and Sudhanoti then we will start this movement from Bagh". For Kashmir this resolution approved to be guarantee for peaceful life and consistency and it became popular in all parts of State and the Valley of Kashmir was echoing by sound of "long live Pakistan". ${ }^{28}$

According to Joseph, Ibrahim Khan, since June had traveled throughout the country, arousing the spirit of his fellow citizens. In August he narrowly escaped arrest in Srinagar and fled to Pakistan. At Murree he laid the foundation for a political movement of liberation, out of which later grew the Azad (Free) Kashmir government. ${ }^{29}$

\section{The Establishment of the Government of Azad Jammu and Kashmir}

After a long struggle, the people of the Jammu and Kashmir acquired complete control of some area of the state, and established the Independent Government of the state of Jammu and Kashmir on Oct 24, 1947. Sardar Ibrahim has written about the establishment of this government in his book as; "On the 24th October 1947, this parallel Government was declared to have been established with its Capital at Pulandri, a small town on a southern side of Poonch along the Jehlam River. I was unanimously voted as the first president of the liberated areas of Kashmir, named Azad Jammu and Kashmir. The working committee of All Jammu and Kashmir Muslim Conference unanimously endorsed this. The Government, which I had then formed, comprised the following members:

1. Sardar Muhammad Ibrahim Khan

2. Syed Ali Ahmed Shah

3. Ch. Abdullah Khan Bahalli

4. Kh. Ghulam Din Wani

5. Syed Nazir Hussain Shah

6. Mir Waiz Muhammd Yousif Shah

7. Khawaja Sanaullah Shamim
(President)

(Defense Minister)

(Revenue Minister)

(Home Minister)

(Finance Minister)

(Education Minister)

(Civil Suppliers)" 30

In reference to the establishment of the Independent government of the State on Oct 24, 1947, different historians have made the analysis.

Christopher Snedden has described that, ""On 24 October 1947, at the second attempt, senior Muslim Conference politicians successfully formed a provisional Azad Government." 31

\footnotetext{
${ }^{28}$ Ibid

${ }^{29}$ Josef Korbel, “Danger in Kashmir”, Published: Oxford printing press, Pakistan, Printed; Kagzi Printers, Karachi. p.67

${ }^{30}$ Sardar Muhammad Ibrahim Khan, “Kashmir Saga” Vari Nag Publisher Mirpur p. 116

${ }^{31}$ Christopher Sneddhan, “The Untold Story of the People of Azad Kashmir”, Hurst \& Co. (Publishers) Ltd., p.58
} 
Professor Nazir Ahmed Tissna wrote, "The Mujahedeens have properly established the government of the State of Azad Jammu and Kashmir on Oct 24, 1947. Sardar Muhammad Ibrahim Khan became its first president. Capital was made near Janjal Hills". ${ }^{32}$

Prime Minister Azad Kashmir in his massage on 70 Youm-e-Tasees said that, "In response to the Mahraja's oppression the military movement was started in Muzzafrabad, Poonch and Mirpur under the leadership by ex-army persons of this region. Thus liberating 4144 square $\mathrm{km}$ area at Janjal Hills in Palandri on Oct 24, 1947 under the leadership of Gazi-e-Millat Sardar Muhammad Ibrahim Khan which established the basis for very first revolutionary government."

Dr. Sarwar Abbasi said, "On Oct 24, 1947 Sardar Ibrahim under his President ship he has announced the constitution of first government of the State of Azad Jammu and Kashmir."33

Josef Korbel said, "This Movement was led by a young Kashmiri, Sardar Muhammad Ibrahim Khan, who since June had traveled throughout the country. In August he narrowly escaped arrest in Srinager and feld to Pakistan. At Muree he led the foundation for a political movement of liberation, out of which later grew the Azad (Free) Kashmir Government." ${ }^{34}$

Victoria Schofield wrote, "The Maharaja has passed an Order to massacre the Muslims, A thirty two year old Sardar Muhammad Ibrahim Khan, collected together the ex-soldiers amongst the Suddhans.'We got army from here and there and then we started fighting the Maharaja's Army'. In about two months he says he had organized an army of about 50,000." 35

Thus due to the efforts of Sardar Ibrahim Azad Jammu and Kashmir could have their first Independent Government.

\section{CONCLUSION}

Ghazi Millat Sardar Mohammad Ibrahim Khan was a great leader. He felt the pain of the nation in his heart and resigned from the government's job and chose the danger path of politics. He was the representative of a nation that was a victim of Maharaja's oppression, social injustice and economic disadvantages. His dream was the complete independence of the state and Jammu and Kashmir and accession with the state of Jammu and Kashmir with Pakistan. According to him; "Pakistan is incomplete without Kashmir; and Kashmir has no identify without Pakistan."

\footnotetext{
${ }^{32}$ Nazir Ahmed Tishna, "Metal-e-Kashmir" , Lahore : Maqbool Academy, p 160

${ }^{33}$ Dr. Sarwer Abbasi, "Siyasyat-e-Kashmir” Rawalpindi: F.I Publisher, p.77

${ }^{34}$ Josef Korbel, "Danger in Kashmir”, Karachi: Oxford Printing Press, p.67

${ }^{35}$ Victoria Schofield, "Kashmir in Conflict: India Pakistan and the unending war". (revised addition)London: I.B.Tauris \& Co Ltd. London. Pp 41-42
} 


\section{REFERENCES}

Abbasi. M. S. Kashmiri Musalmau ki Jehdojehd-e-Azadi. Muzaffarabad: IKS AJKU. 1990

Abbasi. M. S. Siyasyat-e-Kashmir. Rawalpindi: F.I Publisher 1987

Dogre, R.C. Jammu and Kashmir, Mirpur: Verinag Publishers, 1991

Gardazi. S.H.S. Tareekh-a-Aazadi-e-Kashmir ka Paasa Manzar. Mirpur: Vari Nag Publisher, 2003

Hasrat. R. Gazni say Kashmir Tak Dastan Mardan Hurr 'Sudhan’ Dairatul Muarif. Rawalpindi: Waqas Innayat Publishers Foundation, 2012

Hijazi, S.M.G. Tarikh Tehrik-e-Kashmir Inqlab Poonch 1947. Mirpur: Verinag Publisher, 1999

History of the Azad Kashmir Regment (1947-49), First edition. Regimental History Cell: Azad Kashmir regimental center mansar. 1997

Ibrahim. S.M. Kashmir Saga (revised edition), Mirpur: Verinag Publishers, 1990

Jaffar, S.M. Kashmir Soled and Resold. Lahore: Mustafa Wahed Printers, 1992

Jafri, Bashir Hussain Article entitled, 24th October: The birth of the state of Azad Jammu and Kashmir. Published in Business Recorder 2008

Khan Muhammad. Article entitled, Kashmir Independence Day. Published in Pakistan Observer. 2017

Khan. M. Sardar Muhammad Ibrahim Khan ki Sayasi Sawan-e-Umri. Lahore: Maqbool Academy, 2011

Khan. S.M.I. Kashmir Saga. Mirpur: Varinag Publisher, 1965

Korbel, J. Danger in Kashmir, Karachi: Oxford printing press, 2002

Rehman, S. Azad Kashmir and British Kashmiries: History, Politics, community and Identity. Mirpur: National Institute of Kashmir Studies, 2013

Schofield. V. Kashmir in Conflict: India Pakistan and the unending war. (Revised addition) London: I.B.Tauris \& Co Ltd., 2010

Sneddhan. C. The Untold Story of the People of Azad Kashmir, Hurst \& Co. (Publishers) Ltd., 2012

Tariq, M.S.C. Kashmir in Strangulation (Second edition), Islamabad: Pictorial printers. 2003

Tishna, N. A. Metal-e-Kashmir. Lahore: Maqbool Academy. 1993 